\title{
A CROSS SECTIONAL STUDY OF LIPID PROFILE IN NON-DIABETICS WITH STROKE IN URBAN CHITRADURGA
}

\author{
S.B. Vijeth, *V. Mangasuli, A.M. Amrutha, \\ N. Bhoovanchandra, B. Sidenur \\ BASAVESHWARA MEDICAL COLLEGE AND HOSPITAL, CHITRADURGA, INDIA
}

\begin{abstract}
Background. The amount of evidence regarding the relation between serum lipids, lipoproteins and cerebrovascular accident is not adequate. The atherogenecity of diabetics and non-diabetics are different. Therefore, non-diabetic patients were included in the study.

Objective. To study lipid abnormalities in non-diabetic stroke patients in our setup.

Methods. The study was carried out at the Department of General Medicine, BMCH, Chitradurga, during the period from June 2020 to December 2020. The lipid profile and the fasting blood sugar rates of 50 stroke patients without diabetes were studied. Their serum samples were assessed for fasting blood glucose (FBG), total cholesterol (TC), triglycerides (TG), low density lipoprotein cholesterol (LDL) and high-density lipoprotein cholesterol (HDL) by using standard biochemical methods.

Results. The age distribution of the subjects was from 19 to 72 years with a mean age of patients $54.8 \pm 15.75$ years. Among patients 31 (62\%) were males and 19 (38\%) were females. Among the study subjects 58\% were hypertensive, 76\% were smokers, 32\% were alcoholics and 34\% had family history of cerebrovascular accident. Among ischemic stroke group, the most common deranged value in the ischemic group was decreased HDL deranged in $54.1 \%$ of patients; the second most common deranged value - increased VLDL deranged in $40.5 \%$. Among the hemorrhagic group the most common deranged value was also decreased HDL, which was deranged in $46.1 \%$ of patients and the second most common deranged value - increased total cholesterol, which was deranged in $53.8 \%$ patients.
\end{abstract}

Conclusion. Lipid profile should be considered while predicting the risk of stroke.

KEYWORDS: lipid profile; dyslipidemia; non-diabetic stroke; serum cholesterol.

\section{Introduction}

As per World Health Organization, stroke is defined as a clinical syndrome consisting of rapidly developing clinical signs of focal (at times global) disturbance of cerebral function, with duration lasting more than 24 hours or leading to death with no apparent cause other than that of vascular origin [1].

Stroke is the second leading cause of death worldwide causing 6.2 million deaths in 2011 [2]. Stroke is a medical emergency which is an acute neurological injury that occurs due to vascular pathology and presents as a brain infarction or haemorrhage. The modification of risk factors in stroke has brought down both mortality and morbidity of stroke remarkably in the last 30 years. Dyslipidemia is a major risk factor for stroke. It has been established that reduction of total cholesterol, LDL cholesterol, trigycerides, VLDL cholesterol and increasing

*Corresponding author: Vijayalaxmi Mangasuli, Assistant Professor, Basaveshwara Medical College and Hospital, Chitradurga, Karnataka, 577501, India. E-mail: dr.vijugokak@ gmail.com
HDL cholesterol by drugs decreases the incidence of stroke.

In our study, lipid profile was studied in non-diabetic patients with stroke. Diabetes itself is associated with hyperlipidemia and increased atherosclerosis which makes it an undisputed risk factor for stroke. The atherogenecity of diabetics and non-diabetics are different. With this background, we conducted the study of lipid profile in the non-diabetics with stroke in our setup.

\section{Methods}

Patients with stroke and non-diabetic attending OPD and IPD of the Department of General Medicine of Basaveshwara Medical College and Hospital, Chitradurga, were enrolled in the study. Patients with haemorrhagic strokes, embolic strokes, past/present $\mathrm{H} / \mathrm{O}$ diabetes mellitus or history of head injury or usage of anti-coagulant drugs were excluded from the study.

The study took place over the period of 6 months from June 2020 to December 2020. 
Sample size estimation was performed using open epi software version 2.3 .1 at $95 \%$ confidence level, $80 \%$ power of the study, proportion of cases with stroke with raised lipid parameters as $70 \%$ [3]. Sample size estimated was 37 inflated to 50.

A brief personal history and medical history, including brief histories about co-existing disease states, family history of diabetes mellitus, and history of hypertension, past and present illnesses, dietary pattern, addiction and medication were recorded in self prepared questionnaire. Detailed general physical examination, systemic examination and neurological examination were performed to all the patients and were recorded.

The investigations done for the patients at presentation included fasting lipid profile (serum total cholesterol, serum triglycerides, serum high density lipoproteins, serum very low density lipoproteins, serum low density lipoproteins) and HbA1c levels [4].

Data was entered in excel sheet and analysed using the Statistical Package for the Social Sciences 20 (SPSS Inc. Chicago). Results were presented in tabular and graphical forms. Mean, median, standard deviation and ranges were calculated for quantitative data. The Chi square analysis was used in testing for significant differences between proportions and frequencies. The T-test was used in testing for significant differences between two means. The confidence interval was set at $95 \%$ limit, with level of significance, $p \leq 0.05$.

\section{Results}

50 patients were enrolled in the study. The age distribution of the subjects was between
19 to 72 years with mean age of patients $54.8 \pm 15.75$ years. 31 (62\%) were males and 19 (38\%) were females. It was established that $58 \%$ of our study subjects were hypertensive, $76 \%$ were smokers, 32\% were alcoholics and 34\% had family history of CVA (Table 1).

Analysis of lipid profile among both the groups of stroke, i.e., hemorrhagic and ischemic stroke, revealed that the most common rate deranged in the ischemic group was decreased $\mathrm{HDL}$, which is deranged in $54.1 \%$ of patients and the second most common rate deranged was increased VLDL, which was deranged in $40.5 \%$. Among the hemorrhagic group the most common deranged rate was also decreased HDL, which was deranged in $46.1 \%$ of patients, and the second most common deranged rate was increased total cholesterol, which was deranged in $53.8 \%$ of patients (Table 2 ).

Our study concluded a significant association between serum total cholesterol, triglyceride, LDL level, VLDL level and risk of stroke. High levels of total cholesterol, triglycerides, LDL cholesterol were associated with higher risk of stroke. Lowered HDL cholesterol levels were not significantly associated with stroke. The ratio of $\mathrm{HDL} / \mathrm{LDL}$ cholesterol, TC/HDL cholesterol for males and females was evaluated. However, the association with risk of stroke was not found (Table 3).

\section{Discussion \\ Association of Total Cholesterol to the Non-Diabetics with Stroke}

Our study involved 50 subjects and total cholesterol was elevated in the non-diabetics with stroke. The serum total cholesterol levels in cases of either ischaemic or haemorrhagic

Table 1. Risk factors of stroke among study participants

\begin{tabular}{|c|c|c|c|c|}
\hline \multicolumn{2}{|c|}{ Variables } & $\begin{array}{l}\text { Hemorrhagic Stroke } \\
\qquad(n=13)\end{array}$ & $\begin{array}{l}\text { Ischemic Stroke } \\
\qquad(n=37)\end{array}$ & Chi-square test \\
\hline \multirow[t]{2}{*}{ Gender } & Male & $9(69.2)$ & $22(59.5)$ & \multirow{2}{*}{$\begin{array}{c}0.4 \\
p=0.5\end{array}$} \\
\hline & Female & $4(13.8)$ & $15(40.5)$ & \\
\hline \multirow[t]{3}{*}{ Age in years } & $<30$ & $1(7.6)$ & $2(5.4)$ & \multirow{3}{*}{$\begin{array}{c}1.4 \\
p=0.5\end{array}$} \\
\hline & $30-60$ & $6(46.2)$ & $24(64.9)$ & \\
\hline & $>60$ & $6(46.2)$ & $11(29.7)$ & \\
\hline \multirow[t]{2}{*}{ Hypertension } & Present & $9(69.2)$ & $20(54.1)$ & \multirow{2}{*}{$\begin{array}{c}0.9 \\
p=0.3\end{array}$} \\
\hline & Absent & $4(30.8)$ & $17(45.9)$ & \\
\hline \multirow[t]{2}{*}{ Smoking } & Yes & $8(61.5)$ & $30(81.1)$ & \multirow{2}{*}{$\begin{array}{c}2.01 \\
p=0.2\end{array}$} \\
\hline & No & $5(38.5)$ & $7(18.9)$ & \\
\hline \multirow[t]{2}{*}{ Alcoholic } & Yes & $5(38.5)$ & $11(29.7)$ & \multirow{2}{*}{$\begin{array}{c}0.34 \\
p=0.6\end{array}$} \\
\hline & No & $8(61.5)$ & $26(70.3)$ & \\
\hline \multirow[t]{2}{*}{ Family h/o CVA } & Present & $5(38.5)$ & $12(32.4)$ & \multirow{2}{*}{$\begin{array}{c}0.16 \\
p=0.7\end{array}$} \\
\hline & Absent & $8(61.5)$ & $25(67.6)$ & \\
\hline
\end{tabular}


Table 2. Lipid profile among cases and controls

\begin{tabular}{|c|c|c|c|c|}
\hline \multicolumn{2}{|c|}{ Variables } & $\begin{array}{l}\text { Hemorrhagic Stroke } \\
\qquad(\mathrm{n}=13)\end{array}$ & $\begin{array}{l}\text { Ischemic Stroke } \\
\qquad(n=37)\end{array}$ & Chi-square test \\
\hline \multirow[t]{3}{*}{ Total Cholesterol } & $<200$ & $7(53.8)$ & $24(64.8)$ & \multirow{3}{*}{$\begin{array}{c}0.6 \\
p=0.5 *\end{array}$} \\
\hline & $200-240$ & $5(38.5)$ & $9(24.3)$ & \\
\hline & $>240$ & $1(7.7)$ & $4(10.9)$ & \\
\hline \multirow[t]{3}{*}{ Serum Triglyceride } & $<150$ & $6(46.1)$ & $21(56.8)$ & \multirow{3}{*}{$\begin{array}{c}0.7 \\
p=0.5 *\end{array}$} \\
\hline & 150-199 & $4(30.8)$ & $11(29.7)$ & \\
\hline & $200-499$ & $3(23.1)$ & $5(13.5)$ & \\
\hline \multirow[t]{4}{*}{ LDL cholesterol } & $<100$ & $7(53.8)$ & $17(45.9)$ & \multirow{4}{*}{$\begin{array}{c}0.5 \\
p=0.5 *\end{array}$} \\
\hline & $100-130$ & $1(7.7)$ & $9(24.4)$ & \\
\hline & $131-160$ & $3(23.1)$ & $5(13.5)$ & \\
\hline & $>160$ & $2(15.4)$ & $6(16.2)$ & \\
\hline \multirow[t]{2}{*}{ HDL cholesterol } & $<40$ & $6(46.1)$ & $20(54.1)$ & \multirow{2}{*}{$\begin{array}{c}0.24 \\
p=0.6\end{array}$} \\
\hline & $\geq 40$ & $7(53.8)$ & $17(45.9)$ & \\
\hline \multirow[t]{2}{*}{ VLDL cholesterol } & $\leq 30$ & $6(46.1)$ & $22(59.5)$ & \multirow{2}{*}{$\begin{array}{c}0.7 \\
p=0.4\end{array}$} \\
\hline & $>30$ & $7(53.8)$ & $15(40.5)$ & \\
\hline
\end{tabular}

Note. * - Fisher's Exact Test.

Table 3. Comparison of lipid profile between types of stroke

\begin{tabular}{|l|c|c|c|}
\hline \multicolumn{1}{|c|}{ Lipid Component } & $\begin{array}{c}\text { Mean Value in Ischemic } \\
\text { Stroke }\end{array}$ & $\begin{array}{c}\text { Mean Value in Hemorrhagic } \\
\text { Stroke }\end{array}$ & P Value \\
\hline TC & 171.5 & 214.7 & 0.001 \\
\hline Serum TG & 138.2 & 163.7 & 0.018 \\
\hline HDL & 43.4 & 45.8 & 0.822 \\
\hline LDL & 100.5 & 136.1 & 0.004 \\
\hline VLDL & 27.6 & 32.7 & 0.174 \\
\hline
\end{tabular}

stroke were high (10\%) (total cholesterol >240 mg\% according to the Adult Treatment Panel (ATP) - the $3^{\text {rd }}$ guidelines of National Cholesterol Education Program (NCEP)).

Similar studies by Sreedhar K et al. [5] Benfante et al. [6], Di Mascio et al. [7] showed both ischemic and hemorrhagic stroke were associated with increased cholesterol levels.

Contrary to our study, Iso et al. [8] emphasized an inverse association between serum cholesterol level and hemorrhagic stroke. There was no correlation between serum cholesterol and risk of stroke in a study by Harmsen et al. [9] Rastenyte et al. [10] and Hart CL et al. [11]

Association of Triglycerides to the Non-

\section{Diabetics with Stroke}

It was established that serum triglycerides were high in $23.1 \%$ of hemorrhagic stroke patients and $13.5 \%$ of ischemic stroke patients (>200 mg\% according to ATP $-3^{\text {rd }}$ guidelines). Sreedhar K et al. [5] in his study showed $80 \%$ of non-diabetic stroke patients with S.triglyceride $>200 \mathrm{mg} / \mathrm{dl}$ had ischemic stroke and the other $20 \%$ had hemorrhagic stroke. Tilvis R.S et al. [12] in his study showed serum triglyceride was higher in ischemic stroke. Farid et al. [13] also had similar results in his study in 1972. Hachinski et al. [14] showed a positive association of triglycerides in patients with atherothrombotic stroke and transient ischemic attacks compare to the control subjects. Albucher J.K et al. [15] 2000 showed serum triglycerides in normal range in the study on stroke.

Association of Serum HDL Cholesterol to the Non-Diabetics with Stroke

In the study of HDL cholesterol in stroke patients, it was found out that the ischemic group $(54.1 \%)$ patients had greater abnormal levels (<40mg\% according to ATP $-3^{\text {rd }}$ guidelines) than the haemorrhagic group (46.1\%). Simons et al. [16] study revealed that HDL cholesterol had protective effect on ischemic stroke. Alok Mohankar et al. [17] in 1993 showed that increased LDL levels and low HDL levels were associated with atherosclerosis. Albucher et al. [15] study clearly indicated HDL - cholesterol as the only lipid associated with stroke risk. It emphasised the need for management of low HDL cholesterol in young patients regardless of atherosclerosis. 


\section{Association of Serum LDL Cholesterol to the Non-Diabetics with Stroke}

Among ischemic stroke cases, $16.2 \%$ had high LDL cholesterol and this was $15.4 \%$ among haemorrhagic stroke cases. Sreedhar K et al. [5] showed that high levels of serum LDL cholesterol had significant risk of ischemic stroke in the non-diabetics. Botet et al. [18] and Hachinski et al. [14] showed positive correlation between LDL cholesterol levels and risk of stroke. Kurth T et al. [19] 2007 showed remarkable increase in serum LDL levels in ischemic stroke patients.

Association of Serum VLDL Cholesterol to the Non-Diabetics with Stroke

In our study, among ischemic stroke cases $40.5 \%$ had increased VLDL cholesterol and this was $53.8 \%$ among haemorrhagic stroke cases. Bidyadhar et al. [20] 1984 showed that VLDL was increased in their study on stroke. Sreedhar K et al. [5] in the study showed that high VLDL was not associated with risk of stroke in nondiabetic patients.

\section{Conclusions}

According to our study the conclusion can be drawn that the most common type of lipid abnormality were abnormal triglycerides, abnormal VLDL, abnormal LDL. So, these parameters should be considered while predicting the risk of stroke in a dyslipidemic patient. Stroke patients with dyslipidemia need a comprehensive health care approach involving dietician, physician and good bio chemistry back up. In Indian scenario, where majority of the patients belong to the low socio-economic status, life style modification plays a more important role in prevention and management of stroke and dyslipidemia in contrast to high cost of lipid lowering agents.

\section{Conflict of Interests}

Authors declare no conflict of interest.

\section{Author's Contributions}

Dr. Vijeth S.B., Dr. Vijayalaxmi Mangasuli, Dr. Amrutha A.M., Dr. Bhoovanchandra N., Dr. Bhagyalaxmi Sidenur - conceptualization, methodology, formal analysis, writing - original draft, writing - reviewing and editing; Dr. Vijeth S.B., Dr. Vijayalaxmi Mangasuli, Dr. Amrutha A.M. investigation, formal analysis.

\section{ПОПЕРЕЧНЕ ДОСІЛДЖЕННЯ ПОКАЗНИКІВ ЛІПІДНОГО ПРОФІЛЮ У ПАЦІЄНТІВ-НЕДІАБЕТИКІВ, КОТРІ ПЕРЕНЕСЛИ ІНСУЛЬТ, МІСТА ЧИТРАДУРГА}

S.B. Vijeth, *V. Mangasuli, A.M. Amrutha, N. Bhoovanchandra, B. Sidenur BASAVESHWARA MEDICAL COLLEGE AND HOSPITAL, CHITRADURGA, INDIA

Вступ. Зв'язок між рівнем сироваткових ліпідів, ліпопротеїнів та частотою розвитку порушень мозкового кровообігу не є достатньо доведеним. Оскільки рівень атерогеності діабетиків та недіабетиків є різним, тому в дослідження були включені пацієнти без діабету.

Мета. Вивчення порушень ліпідного обміну у пацієнтів з недіабетичним інсультом у місцевій лікарні.

Методи. Дослідження проводилося у General Medicine Department, BMCH, Chitradurga протягом періоду з червня 2020 року по грудень 2020 року. Вивчався ліпідний профіль та показники глікемії натще у 50 пацієнтів з інсультом без діабету. Визначалися вміст глюкози крові натще (FBG), загального холестерину (TC), тригліцеридів (TG), ліпопротеїдів низької щільності (LDL) ma ліпопротеїдів високої щільності (HDL) за допомогою стандартних біохімічних методів.

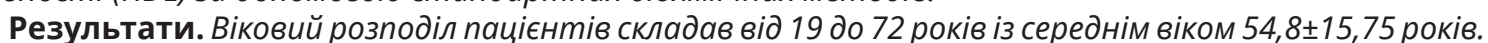
Чоловіки становили 62\% (31), жінки - 38\% (19). Серед досліджуваних 58\% мали гіпертонічну хворобу, 76\% були куриями, 32\% - алкоголіки, а 34\% мали сімейний анамнез із порушенням мозкового кровообігу. Серед групи ішемічного інсульту найчастіше спостерігалося зниження ліпопротеїдів високої шільності (54,1\%), другим найпоширенішим відхиленням було збільшення ліпопротеїдів дуже низької щільності у 40,5\%. Серед групи з геморагічним інсультом найчастіше спостерігалося також зниження ліпопротеїдів високої щільності, яке виявлялося у 46,1\% пацієнтів, другим найпоширенішим відхиленням було збільшення загального холестерину, яке спостерігалося у 53,8\% пацієнтів.

Висновки. Під час прогнозування ризику інсульту слід враховувати ліпідний профіль.

КЛючОВІ СЛОВА: ліпідний профіль; дисліпідемія; недіабетичний інсульт; сироватковий холестерин. 


\section{Information about the authors}

India

Dr. Vijeth S.B., Associate Professor, Basaveshwara Medical College and Hospital, Chitradurga, Karnataka,

ORCID: 0000-0002-6882-2604, e-mail: vijethsb71@gmail.com

Dr. Vijayalaxmi Mangasuli, Assistant Professor, Basaveshwara Medical College and Hospital, Chitradurga, Karnataka, India

ORCID: 0000-0002-2861-2012, e-mail: dr.vijugokak@gmail.com

Dr. Amrutha A.M., Assistant Professor, Basaveshwara Medical College and Hospital, Chitradurga, Karnataka, India

ORCID: 0000-0003-4958-031x, e-mail: amrutha.angadi89@gmail.com

Dr Bhoovanchandra N., Postgraduate, Basaveshwara Medical College and Hospital, Chitradurga, Karnataka, India

ORCID: 0000-0008-2112-3265, e-mail:bhoovan2@gmail.com

Dr Bhagyalaxmi Sidenur, Assistant Professor, Basaveshwara Medical College and Hospital, Chitradurga, Karnataka, India

ORCID: 0000-0001-6012-3166, e-mail: bhagyasidenur@gmail.com

\section{References}

1. World Health Organization. The world health report 2002: reducing risks, promoting healthy life. World Health Organization; 2002.

2. Smith WS, Johnston SC, Hemphill III JC. Cerebrovascular Diseases. In: Kasper DL, Hauser SL, Jameson JL, Fauci AS, Longo DL, Loscalzo J eds. Harrison's Principle of Internal Medicine. 20th ed. McGraw Hill; 2020:2559-86.

3. Kar A, Dash C, Murmu M, KP KM. Study of lipid profile in cases of non-diabetic stroke. International Journal of Advances in Medicine. 2018 Jan 18;5(1): 82-90.

DOI: 10.18203/2349-3933.ijam20180063

4. Nigam PK. Serum lipid profile: fasting or nonfasting. Indian J Clin Biochem 2011;26(1):96-7.

DOI: $10.1007 \% 2 F s 12291-010-0095-\mathrm{X}$

5. Sreedhar K, Srikant B, Joshi L, Usha G. Lipid profile in non-diabetic stroke-a study of 100 cases. J Assoc Physicians India. 2010;58:547-51.

DOI: 10.18203/2349-3933.ijam20180063

6. Benfante R, Yano K, Hwang LJ, Curb JD, Kagan A, Ross W. Elevated serum cholesterol is a risk factor for both coronary heart disease and thromboembolic stroke in Hawaiian Japanese men. Implications of shared risk. Stroke. 1994;25(4):814-20.

DOI: $10.1161 / 01 . S T R .25 .4 .814$

7. Dimascio R, Marchiolli R, Vituollo F, Dipasquale A, Cavasinni L, Tognoni G. Serum cholesterol and risk of ischemic stroke: results of a case-control study. Prev Med. 1995;24(2):128-33.

DOI: $10.1006 /$ pmed.1995.1025

8. Iso $H$, Jacobs DR, Wentworth $D$, Neaton JD, Cohen JD, MRFIT Research Group. Serum cholesterol levels and six-year mortality from stroke in 350,977 men screened for the multiple risk factor intervention trial. N Engl J Med. 1989;320(14):904-10.

DOI: $10.1056 /$ nejm198904063201405
9. Harmsen $P$, Rosengren A, Tsipogianni A, Wilhelmsen $\mathrm{L}$. Risk factors for stroke in middle-aged men in Göteborg, Sweden. Stroke. 1990;21(2): 223-9.

DOI: 10.1161/01.str.21.2.223

10. Rastenyte D, Tuomilehto J, Domarkiene S, Cepaitis Z, Reklaitiene R. Risk factors for death from stroke in middle-aged Lithuanian men. Stroke. 1996;27(4):672-6.

DOI: $10.1161 / 01 . s t r .27 .4 .672$

11. Hart CL, Hole DJ, Smith GD. Risk factors and 20-year stroke mortality in men and women in the Renfrew/Paisley study in Scotland. Stroke. 1999; 30(10):1999-2007.

DOI: 10.1161/01.str.30.10.1999

12. Tilvis RS Erkinjunti J ,Sulkava R et al.Serum lipids and fatty acids in ischemic stroke.American heart journal1987;113;615-619.

DOI: 10.1161/01.str.26.5.778

13. Farid N. R, Anderson. J: Cerebrovascular disease and hyper-lipoproteinemias. Lancet 1, 1398; 1972.

DOI: 10.1016/s0140-6736(72)91136-1

14. Hatchinski V Graffagnino C,Beaudry,Bernier G, Buck,Donner A, SpenceD,DoidG\& WolfeBMF1996. Lipids and stroke a paradox resolved,Arch Neuro53; 303-308

15. AlbucherJF,Ferrieros J et al.serum lipids in young patients with ischemic stroke, a case control study.J Neurology Neurosurgery psychiatry 2000; 69(1);29-33.

DOI: 10.1136/jnnp.69.1.29

16. Simons LA, McCallum J, Friedlander $Y$, Simons J. Risk factors for ischemic stroke: Dubbo study of the Elderly. Stroke 1998;29:1341-1346.

DOI: 10.1161/01.str.29.7.1341

17. Alok mohankar, Ravindrakumar Garg et al. serum lipids and stroke.neurology India 1993. 
18. Botet PJ, Senti M, Nogues X, Rubies-Prat J, Roquer J, D'Olhaberriague $L$ et al. Lipoprotein and apolipoprotein profile in men with ischemic stroke: Role of lipoprotein(a), triglyceride-rich lipoproteins, and apolipoprotein E polymorphism. Stroke 1992; 23:1556-62.

DOI: $10.1161 / 01 . s t r .23 .11 .1556$
19. Kurth T.Everett et al,Lipid levels and the risk of ischemic stroke in women.Neurology $2007 ; 68 ; 556$ 562.

DOI: 10.1212/01.wnl.0000254472.41810.0d

20. Bidyadhar $S$ et al. Plasma lipids and lipoproteins in patients with premature IHD and ICD. Japi 1984;32;11.

DOI: $10.2337 /$ diacare.27.6.1496

Received 19 May 2021; revised 12 Jun 2021; accepted 13 Jun 2021.

This is open access article distributed under the Creative Commons Attribution License, which permits unrestricted use, distribution, and reproduction in any medium, provided the original work is properly cited. 